\title{
QUANTITATIVE PERCEPTIONS OF BACKUS'S E-GOVERNANCE MODEL
}

Alain Michael $\mathrm{MOMO}^{1}$
Received Date (Başvuru Tarihi): 07/05/2019

Accepted Date (Kabul Tarihi): 17/06/2019

Published Date (Yayın Tarihi): 16/09/2019

\section{ABSTRACT}

This study was conducted to determine measures of dispersion for normal distribution of nation brand ranking in line with Backus's e-governance model adoption. The significance of this study dwells in the quantitative interpretations of Backus's e-governance model for rebranding African nations. This is an exploratory study, which is based on the emic perspective (author's viewpoint) built on literature reviewing and inferential statistics. The results show that the probability for investors to select randomly South Africa as business destination P (RSA) is 35\%. The mean of top 10 African nation brands being 61.2; South Africa's brand variance of 156.8; and standard deviation of 5.8 translates better reputation and positioning from the sample $(n)$.

Keywords: E-Governance, Backus's Model \& Quantitative Perceptions

JEL Codes: H70, H83, O3, O38

\section{BACKUS'UN E-DEVLET MODELININ NICELIKSEL ALGILARI}

$\ddot{O} Z$

Bu çalışma, ülke marka sıralamasının normal dağılımına yönelik dağılım ölçütlerini Backus'un e-devlet modelinin benimsenmesi doğrultusunda belirlemek amacıyla yapılmıştır. Bu çalışmanın önemi, Backus'un Afrika uluslarını yeniden markalaştırmaya yönelik e-devlet modelinin niceliksel yorumlarına dayanmaktadır. Bu, literatür taraması ve çıkarımsal istatistiklere dayanan emik bakış açısına (yazarın bakış açısı) dayanan bir keşif çalışmasıdır. Sonuçlar, yatırımcıların Güney Afrika'yı rasgele iş yeri olarak seçme ihtimalinin\% 35 olduğunu göstermektedir. En iyi 10 Afrika ülkesi markasının ortalaması 61.2; Güney Afrika'nın marka varyansı 156.8 ve 5,8'lik standart sapma, örneklemin dopru konumlandırıldı ğını göstermektedir.

Anahtar Kelimeler: E-Devlet, Backus'un Modeli, Niceliksel Algllar

JEL Kodlarl: H70, H83, O3, O38

\footnotetext{
1 Dr., Cape Peninsula University of Technology, Faculty of Business, Marketing Department, Cape Town-South Africa, momomike161@gmail.com https://orcid.org/0000-0002-5850-7360
} 


\section{INTRODUCTION}

Electronic governance (e-governance) is the application of Information Systems (IS) in the processes of public service delivery to induce Simple, Moral, Accountable, Responsive and Transparent (SMART) governance (The World Bank, 2019). Western countries adopted egovernance, therefore transforming public organizations to strong brands engaging with citizens (UN e-governance Survey, 2018).

E-governance adoption based on Backus's model rebranded Asian countries such as India and China. In Africa, public organizations re-branding translates different perceptions to citizens. For some countries, re-branding is merely a logo; and for others, it is an underpinning philosophy (UN e-governance Survey, 2018). However it seems that few government employees in Africa would understand the strategic role of e-governance as rebranding tool.

Visual expression is one aspect of communication, which captures interest and loyalty of citizens. However, effective nation rebranding is less about logo, motto, and banners, rather innovation when engaging with citizens (UN e-governance Survey, 2018). Various studies elaborated on the successful adoption of e-governance models (United Nations, 2018; World Resources Institute, 2017; The World Bank, 2016). However, the significance of this study dwells in the quantitative interpretations of Backus's e-governance model adoption for rebranding African nations.

This paper attempts to determine measures of dispersion for normal distribution of nation brand ranking when adopting Backus's e-governance model. This is an exploratory study based on author's view and built on literature and inferential statistics.

\section{LITERATURE REVIEW}

\subsection{E-Governance}

Government agencies adopt e-governance for various reasons namely information exchange with citizens, faster public service delivery and smart governance reducing value chain costs (UNDESA, 2017). 
With no exaggeration, there is positive relationship between e-governance adoption and the development of computer technology, networking of computers and communication systems. In Africa, the above-mentioned became available with a perceptible time lag as compared to developed nations (UNDESA, 2018).

E-governance proceeds through four phases namely computerization, networking, online presence and online interactivity. In the computerization phase, government departments are equipped with computers, which enable word and data processing. The networking phase includes hub of information sharing and flow of data between different governments entities (The World Bank, 2017).

Increased Internet connectivity and need for maintaining presence on the web translate online presence phase. This results in government websites containing information about organisational structure, contact details, reports and publications being maintained by government departments (Estonia E-Governance Academy, 2017).

The online interactivity phase is a natural consequence of online presence, which opens up communication channels between government departments and citizens. The main aim of Backus's model is to minimize the scope of personal interface with government departments by providing downloadable forms, instructions, acts and rules.

\subsection{Backus's E-Governance Model For Rebranding African Nations}

The study acknowledges the implications of other e-governance models, namely Oracle (2006), Zwahr and Finger (2005). Figure 1 indicates Backus's e-governance model framed around e-commerce concept, making it more relevant in this study. 


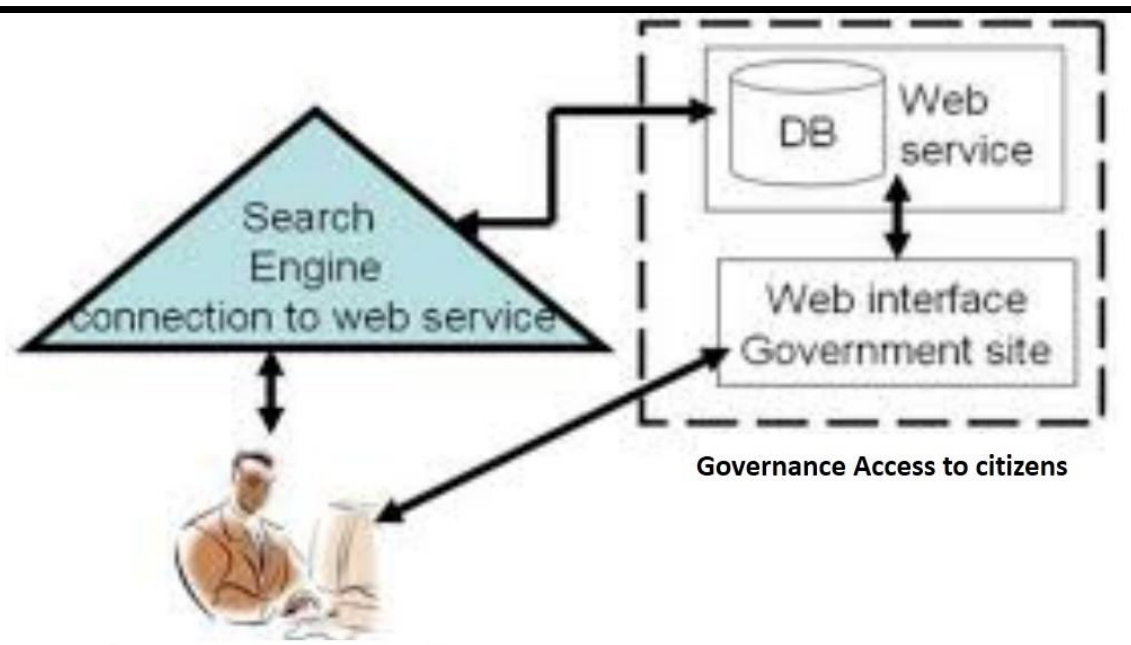

Citizens or Business

Figure 1. Backus's e-governance model for African nation rebranding (The computer graphic stands for any ICT tool (or actors) involved in e-governance) (Source: Mphidi, 2017)

South African e-government provides online services indicated in Table 1.

Table 1. Online services in South Africa

\begin{tabular}{|l|l|}
\hline No & Service \\
\hline 01 & Birth registration \\
\hline 02 & Business registration \\
\hline 03 & Education and training \\
\hline 04 & Youth and relationships \\
\hline 05 & Disability assistance \\
\hline 06 & Job search \\
\hline 07 & Social benefits \\
\hline 08 & Housing and settlements \\
\hline 09 & Tourism information \\
\hline 10 & Sport and recreation \\
\hline 11 & Citizenship application \\
\hline 12 & Enforcement procedure \\
\hline 13 & Retirement and old age \\
\hline 14 & Death registration \\
\hline
\end{tabular}

(Onyancha, 2017) 
In its framework of planning and implementing e-governance, Oracle (2006) spells out business strategy, infrastructures and management skills as components that are mandatory in several activities that need to be accomplished for successful e-governance implementation.

Business strategy is important to clearly define the strategy and implementation plan in order to avoid duplication, wastage of effort, minimize chances of mistakes and lead to the creation of an integrated system. In terms of infrastructures, managers in government departments should specify how various government offices would be interconnected with one another and with external entities (Harwich, 2017).

The hardware description primarily should contain specifications matching service employee's knowledge and skills to improve the processes and avoid service delivery mismatch. Database management is a planning tool enabling electronic version of government information.

Further, to avoid service failure, public service provider has to choose relevant technology from speech interface, security solutions, web hosting, multi-lingual support to middleware (Onyancha, 2017). However, Backus argues that e-governance stages are not always mandatory in the implementation since, even in the Western world, some government departments could be in phase 1, 2 or 3 . Indeed governments start by delivering online information. Thus, public demand and internal efficiency soon require more complex services (World Economic Forum, 2018).

Most importantly, Backus's e-governance model emphasises on a two-way system of communication among the role players namely Government to Citizens (G2B), Citizens to Government (C2G); Government to Business (G2B); Business to Government (B2G); Citizens to Business (C2B) and Business to Citizens (B2C) (World Economic Forum, 2018).

From the above, Backus e-governance model promotes African nation re-branding. The model facilitates $\mathrm{G} 2 \mathrm{~B}, \mathrm{C} 2 \mathrm{G}, \mathrm{G} 2 \mathrm{~B}, \mathrm{~B} 2 \mathrm{G}$ and $\mathrm{C} 2 \mathrm{~B}$ interactions via governmental platform by providing the latter's hyperlinks on the government websites. The hyperlinks may include those pointing the citizens to jobs available in the industry, business tenders and contracts, contact addresses of companies operating in a given province. Table 2 indicates top 10 African nation brands, which invested in improving interactions between government departments and citizens. 
Table 2. Top 10 African Nation Brands

\begin{tabular}{|l|l|l|l|}
\hline Ranking & Country & Brand value & Brand rating \\
\hline 1 & RSA & 218 & A \\
\hline 2 & Egypt & 109 & A- \\
\hline 3 & Nigeria & 88 & BBB \\
\hline 4 & Morocco & 48 & A- \\
\hline 5 & Algeria & 45 & BB \\
\hline 6 & Angola & 31 & B \\
\hline 7 & Tunisia & 24 & A \\
\hline 8 & Kenya & 19 & A- \\
\hline 9 & Ghana & 18 & A- \\
\hline 10 & Ethiopia & 12 & BBB \\
\hline
\end{tabular}

(How we made it in Africa, 2019)

Within their nation-branding journey, African nations would want to explain situations where branding effort outcomes significantly and materially differ from planned, expected and targeted results (DW, 2019). From Table 2, the study engages in the process of standard deviation analysis and probability.

\section{METHODOLOGY}

The study is exploratory and seeks to paint a quantitative picture of Backus's egovernance model for African nation re-branding. The study utilized inferential statistics, which is extremely useful in data analytics to understand and solve nation-branding problems via information systems adoption in government departments (Quora, 2019).

The purpose of using statistical inferences was to conclude about the whole research population at hand. Analysis of variance was the overarching statistical method, which was used to test and analyze the differences between means from the data set. The significant differences between the means were obtained, using this test (Acad Gild, 2019).

To avoid jumping from one transitory conclusion of data to the other, the study was informed by standard deviation in Table 3, which measured the spread of brand value for each African nation brand within the given set of data (Laerd Statistics, 2019).

\section{DATA ANALYSIS AND INTERPRETATION}

Table 3 indicates that the mean of top 10 African nation brands is 61.2. South Africa's brand variance of 156.8, and standard deviation of 5.8 translates better reputation and how far 
the country's image is positioned from the sample (n). RSA, Egypt and Nigeria record positive brand variance.

Furthermore, in the set of top 10 African nation brands, probability of RSA element noted $P(R S A)=\frac{r}{n}$ in Table 3 is a prominent indicator for the local business community. From the experiment drawn, the chance for investors to select RSA randomly as a first business destination in Africa is $35 \%$.

Table 3. Measuring Dispersion Values Of The Top 10 African Nation Brands

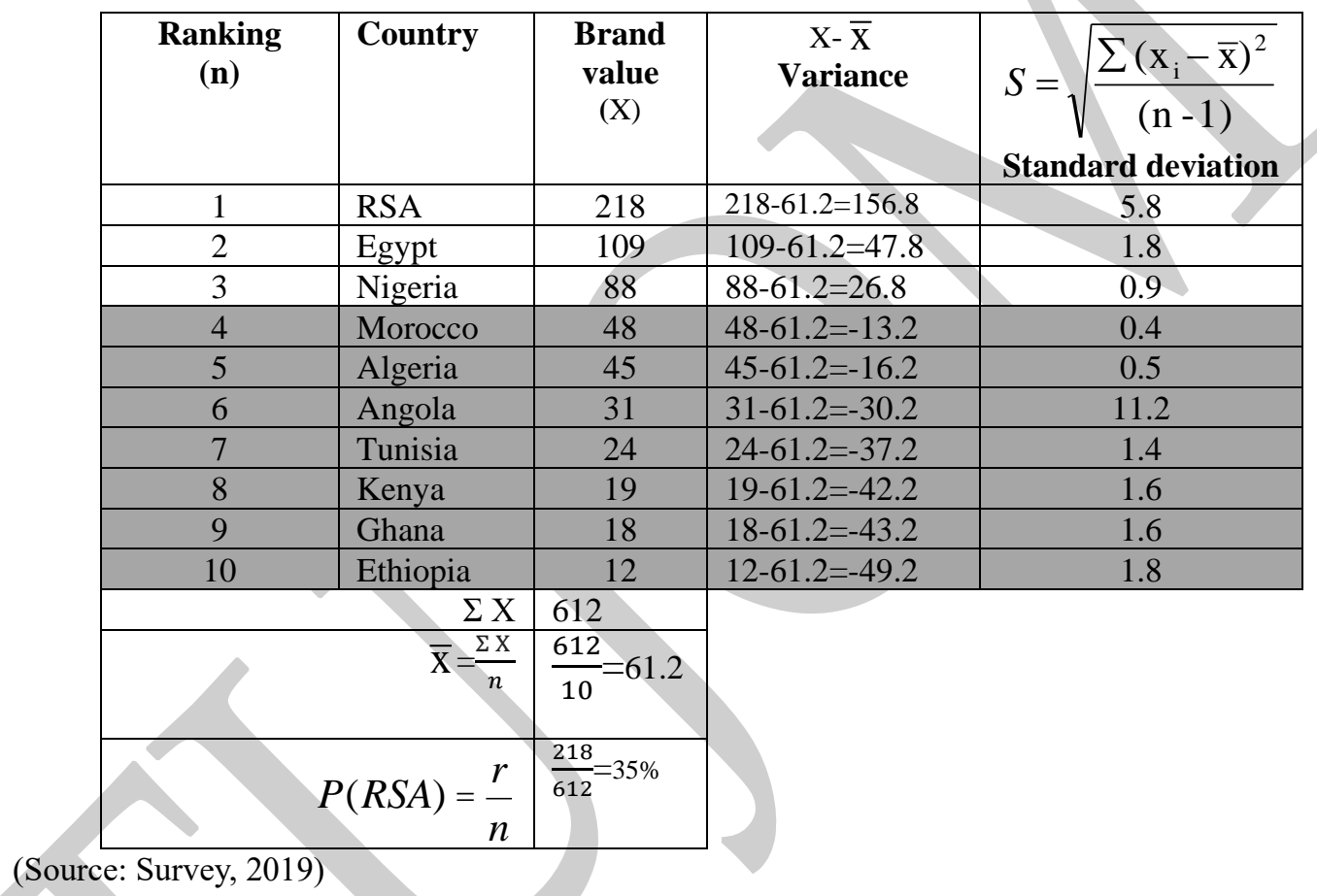

For normal distribution of e-governance resource and nation branding, it is agreeable that simplicity, efficiency and, accountability in the government department underscores the application of information systems to business process re-engineering.

Expanded reach of governance suggests that rapid growth of communications technology and its adoption in governance helped in bringing government departments to the doorsteps of the citizens in South Africa, Egypt and Nigeria.

Expansion of telephone network beyond the average (61.2), rapid strides in mobile telephony, the spread of internet and strengthening of other communications infrastructure facilitated the delivery of a large number of services provided by South African government as indicated in Figure 1. 


\section{Dispersions of top 3 African nation brands}

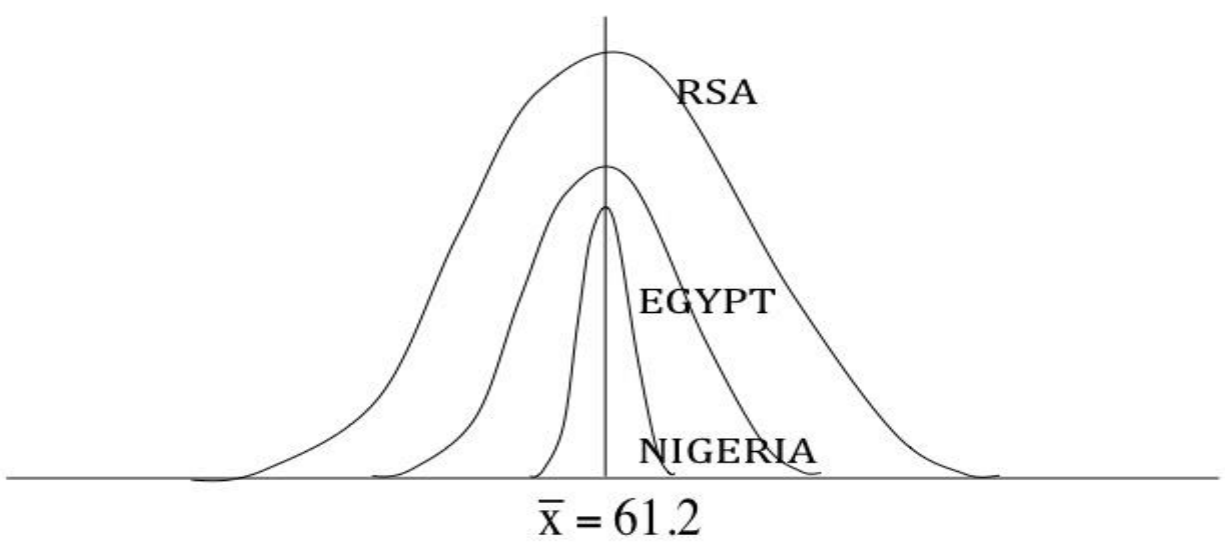

Figure 2. Dispersions Of Top 3 African Nation Brands

Source: Survey, 2019

\section{FINDINGS}

Given variance of 156.8 and standard deviation of 5.8, South African government successfully adopted e-governance inspired from Backus's model.

Findings reveal that the probability for investors to select randomly South Africa as a business destination $P(R S A)=\frac{r}{n}$ is $35 \%$.

Globalization continues to increase at an accelerating rate, competition between South Africa, Egypt and Nigeria has emerged as one of the challenges facing these African governments across the continent. The African market has become a battlefield for savvier citizens, Western and Chinese Multi-National Corporations (MNCs) and African Direct Investment (ADI).

The above has compelled South Africa, Egypt and Nigeria to excel with innovative ways of delivering public services to become the destinations of choice for investments (Sodhi, 2017). Despite negative variance from the Mean (61.2) namely Morroco (-13.2), Algeria (-16.2), Angola (-30.2), Tunisia (-37.2), Kenya (-42.2), Ghana (-43.2) and Ethiopia (49.2), these countries still emerged and cannot fall under the unbranded state nations.

As a result of the above findings, the unbranded state will have a difficult time attracting global attention (Public and cultural diplomacy, 2017). Thus, e-governance process 
strengthens democracy, helps both internal development, regional and global integration. South Africa plays a prominent role in the international marketplace in the Brazil-RussiaIndia-China-South Africa (BRICS) community while standing as national umbrella brand for the SADC region (Public and cultural diplomacy, 2017) and Africa's brand ambassador in the G20.

Thus, a positive brand image can help African countries to reverse the brain drain. One of the consequences of globalization is the haemorrhaging of its best-educated and most talented workers, entrepreneurs and academics to the developed nations. Brain drain remains one of the most difficult challenges, which can be addressed by e-governance adoption in Africa (Public and cultural diplomacy, 2017).

The final finding is that the benefits of Backus's e-governance model include better access to information and quality services for citizens, simplicity, efficiency and, accountability in the government and expanded the reach of governance. Regarding services, there is an immediate impact in terms of savings in time, effort and money, resulting from online and one-point accessibility of public services backed up by automation of back-end processes (The World Bank, 2019).

\section{CONCLUSION AND RECOMMENDATIONS}

More emphasis should be on the extensive implementation and improvement of Backus's e-governance in African countries. Given the similarities like competition, it is not surprising that public service organizations are adopting marketing strategies that parallel private companies.

People tend to think about countries as a complete entity when they are considering whether to visit them, buy their products, or engage with them in some other way. Indeed, people think of countries as brands (Brands and Branding, 2017). South Africa's variance of 156.8 and standard deviation of 5.8 demonstrate that despite challenges, early e-governance adoption indicates nation-re-branding efforts. Even though globalization continues to increase at an accelerating rate, competition between South Africa, Egypt and Nigeria has emerged as one of the challenges facing these African governments across the continent. However, egovernance investment positions South Africa at least at $35 \%$ of probability as a business destination in the continent. The above in return confirms benefits associated with egovernance adoption such as better access to information and quality services for citizens, 
simplicity, efficiency and accountability in the government and expanded the reach of governance in South Africa. 


\section{REFERENCES}

Acad Gild. 2019. Inferential Statistics - Definition and Types. Available at: https://acadgild.com/blog/inferentialstatistics-definition-and-types [Accessed on 24/06/2019].

Brands and Branding. (2017). Building Customer-Based Brand Equity : What Makes A Strong Brand? How Do You Build A Strong Brand? Available at: http:/www.brandsandbranding.co.za/building-customer-based-brandequity-what-makes-a-strong-brand-how-do-you-build-a-strong-brand/ [Accessed on 29/09/2017].

DW. (2019). Germany replaces USA as country with best international image. Available at: https:/www.dw.com/en/germany-replaces-us-as-country-with-best-international-image/a-41407751 [Accessed on $05 / 06 / 2019]$.

Estonia E-Governance Academy (2017). Yearbook 2017. [online] Available at: https://ega.ee/wpcontent/uploads/2018/01/ ega_aastaraamat2017_digital-ENG.pdf [Accessed on 05/05/2019].

Financial Director. (2019). Public Sector Branding: Ignore it at your peril. Available at: https:/www.financialdirector.co.uk/2013/05/09/public-sector-branding-ignore-it-at-your-peril/] [Accessed on 12/05/2019].

Harwich, E. (2017). AI could transform the way governments deliver public services. Published in The Guardian (8 February 2017). Available at: https://www.theguardian.com/public-leaders-network/2017/feb/09/artificialintelligence-robots-transformgovernments-public-services-japan-uk-singapore [Accessed on 02/05/2019].

How we made it in Africa. (2019). Which African countries have the strongest 'nation brands'? Available at: https://www.howwemadeitinafrica.com/which-african-countries-have-the-strongest-nation-brands/17054/ [Accessed on 21/06/2019].

Laerd Statistics. (2019). Standard deviation. Available at: https://statistics.laerd.com/statistical-guides/measuresof-spread-standard-deviation.php [Accessed on 24/06/2019].

Quora. (2019). Why is inferential statistics important? Available at: https://www.quora.com/Why-is-inferentialstatistics-important [Accessed on 06/07/2019].

The World Bank. (2017). Promoting e-Governance - The SMART Way Forward. Available at: http://arc.gov.in/11threp/arc_11threport_ch2.pdf [Accessed on 26/09/2017].

The World Bank. (2016). World Development Report 2016: Digital Dividends. Available at: http://www.worldbank.org/ en/publication/wdr2016 [Accessed on 20/05/2019].

UN e-governance Survey, (2018). UN E-Government Survey 2018. Available at: https://publicadministration.un.org/egovkb/en-us/Reports/UN-E-Government-Survey-2018 [Accessed on 06/07/2019]. 
United Nations. (2018). High-Level Political Forum 2018. Available at: https://sustainabledevelopment.un.org/hlpf/2018 [Accessed on 05/06/2019].

United Nations. (2018). World Resources Institute, 2017; The World Bank, 2016.

UNDESA. (2017). Guides on Lessons for Open Government Data Action Planning for Sustainable Development. Available at: http://workspace.unpan.org/sites/Internet/Documents/UNPAN97913.pdf [Accessed on $07 / 05 / 2019]$.

UNDESA. (2018). Working Together: Integration, institutions and the Sustainable Development Goals. World Public Sector Report 2018. Division for Public Administration and Development Management. New York. April.

World Economic Forum. (2018). The Global Risk report 2018. Available at: https://www.weforum.org/reports/the-globalrisks-report-2018 [Accessed on 02/06/2019].

World Resources Institute. (2017). How Artificial Intelligence Helped Us Predict Forest Loss in the Democratic Republic of the Congo. Available at: http://www.wri.org/blog/2017/07/how-artificial-intelligence-helped-uspredict-forest-lossdemocratic-republic-congo [Accessed 30/04/2019]. 